\title{
TRINITARIAN NATURAL THEOLOGY AND THE ARGUMENT FROM TRUE LOVE
}

\section{Borut Pohar University of Ljubljana. Slovenia}

\begin{abstract}
Christian apologetics has recently gained a new impetus from authors such as Alister McGrath, who advocates a new, Trinitarian approach to natural theology, the main purpose of which is to confirm a resonance between scientific discoveries and Christian doctrine, thus confirming its credibility. In this article, we use Trinitarian natural theology, which has many advantages over classical natural theology, on the example of the surprising phenomenon of true love. This is manifested in the material world in The Principle of Insufficient Reason, observable through observations of deeds of love, which lack reciprocity and, in the lifeworld in the essence of ratio-sui or selfexplicability of true love, experienceable through experiences of explanation of the reasons for love with love itself. The analysis of different layers of reality and its scientific methods, together with the postpositivistic recognition of the plurality of methods, has shown that the method of inference to the best explanation, which is used in the article, is a legitimate scientific method. The Christian doctrine of the Triune God of Love and the doctrine of perichoresis make perfect sense of the empirical observations and lifeworld experiences of true love. However, the question remains unanswered: which of the worldviews best explains the curious and surprising phenomenon of true love?
\end{abstract}

Keywords: Trinitarian natural theology, postpositivism, inference to the best explanation, principle of insufficient reason, self-explicability, true love

\section{INTRODUCTION}

Christian apologetics in the form of natural theology, seemingly defeated during the reign of positivism, has experienced a renaissance in recent decades due to the rise of postpositivism, which introduced new insights into the field of epistemology, such as the theory-ladenness of observations. One of the important thinkers advocating for its rehabilitation, although in a fundamentally different form, is Alister McGrath, a convert from atheism and the founder of the Oxford Centre for Christian Apologetics. McGrath has issued many books promoting Trinitarian natural theology as a useful tool for 
demonstrating the resonance between the Christian vision of Triune God and scientific findings. In his book Mere Apologetics, he $(2012,111)$ confidently states: "There is strong resonance between theory and observation - between the theological framework and the realities of our personal experience." The difference between classical natural theology and Trinitarian natural theology is not only the difference in the method and purpose (the former searches for the logical proof of God's existence) but also in the conception of God. While classical natural theology speaks about God as the supreme being, the Trinitarian natural theology highlights its Triune character: that God exists in the form of Holy Trinity, in which the Father, the Son, and the Holy Spirit abide in true love. Hence, the Christian Trinitarian God is the God of true love.

In this article, we attempt to apply his vision of Trinitarian natural theology to compose the Argument from True Love, with which we want to confirm the credibility of the Christian faith by showing that our observations and experiences of the surprising phenomenon of true love fit in with the Christian doctrine. This is in accordance with McGrath's vision of apologetics. He (2008, 234) says:

The agenda is not, therefore, 'proof' of core Christian beliefs, but the demonstration of resonance between theory and observation, leading to an enhanced commitment to the theory that is able to explain and account for so much that is observed.

In this article, we use the mountain-body model of understanding (Cf. Pohar 2021), which presupposes four different layers of reality and, consequently, four different types of methods, which will be explained below. However, before trying to confirm the reasonableness of the Christian worldview with the Argument from True Love, we must first show that our method of inference to the best explanation is legitimate and trustworthy. For this reason, we will continue with the clarification of the methods used in this article to remove any misunderstandings or doubts.

\section{THE METHODS}

In this contribution, three methods are used: (1) the scientific deductive empirical method of abstraction for the creation of the Principle of Insufficient Reason, (2) the phenomenological method of eidetic reduction for the discovery of the selfexplicability of true love, and (3) the scientific inductive method of inference to the best explanation for demonstrating of the resonance between both findings and the Christian doctrine. First, let us explain that there is not just one scientific method, as incorrectly claimed by philosophers of the previous Modern era.

\section{The plurality of methods and the idea of stratified reality}

To demonstrate that Christian doctrine is the best explanation of observations and other types of experience (lifeworld, life) of true love, we must first refute two myths that prevent legitimate use of the apologetic method of the inference to the best 
explanation, which is sometimes criticized as unreliable or non-scientific: (1) the myth that there is one single scientific method, which is the same for all times and for all scientific disciplines. (2) The myth of the ontological uniformity of the world and the myth of scientific ontological reductionism, which, according to Martin C. Dillon $(1988,16)$ claims that "the objects of science - the things we can truly know - are irreducible quanta which are the products of exhaustive analysis and which lend themselves to the precision of mathematical calculation and processing." In this article, we attempt to demonstrate on the basis of the mountain-body model of understanding that in addition to the material world, there are three other layers of reality that are also in the domain of science.

Logical positivists wanted to discover a universal scientific method that would be the same for all disciplines and for all times. One of their proposed possibilities was the hypothetico-deductive method, which was supposed to be based on neutral observations and inductive logic. Their critic Karl Popper advocated the method of falsification (Sankey 2008, 248-257). Those times, however, have ended. James Garrison $(1986,12)$ says: "It is widely held that positivism is dead and that we now live in a postpositivistic era of educational research." It had turned out that logical positivism faces severe problems. First, theory and observation are not independent, which makes truly objective observation impossible (i.e., the theory-ladenness of observation) (Bem and De Jong 2006, 63). Secondly, in practice, scientists use more than one method. According to Howard Sankey (2008, 255), the postpositivists came to a conclusion that "the method consists of a plurality of rules which may be employed in the evaluation of scientific theories or in the certification of empirical results." One of the methods often used in science is the method of inference to the best explanation, a method crucial for our argumentation.

The fact of the plurality of methods leads to an a posteriori conclusion: that there is more than one single ontological layer of reality and that reality is stratified. McGrath (2006, 107) says:

... such a stratification of reality is both demanded by a posteriori reflection on the scientific enterprise and by the Christian vision of the nature of the world

... Every level of reality demands to be investigated on its own terms, which are established $a$ posteriori by reflection on the way things are, not determined a priori in advance of any such interpretation.

Now we will present four such ontological levels of reality, which are highlighted in the mountain-body model of understanding (Cf. Pohar 2021). They are inextricably linked to the specific types of meaning perception and reasoning (i.e., specific a posteriori scientific methods), which investigate each of them. In the case of the Argument from True Love, we will use all of them.

\section{The domains of science and its methods}

(1) Every domain of science explores one of the four ontological layers of reality: (1) material world, (2) lifeworld, (3) material life, and (4) personal life. These four 
layers are structured similarly to planet earth, which also has four main layers: the crust, the mantle, the outer core, and the inner core. The outermost part or the crust of reality is the material world with its regularities, which are observed by scientists. From the observations, which are acquired by the method of deductive abstraction, the scientists then deduce principles with the help of deductive rules, and then turn them into empirical (scientific) laws with the help of deductive universalization. The most ancient type of reasoning, put forward by the ancient philosopher Aristotle, is deduction, which played an important role in the first period of modern science. Since Aristotle, scientific inquiry has included observation and reasoning about the natural world. The Stanford Encyclopedia of Philosophy (2001, s.v. "Scientific Method") says: "In addition to careful observation, then, [the] scientific method requires a logic as a system of reasoning for properly arranging, but also inferring beyond, what is known by observation." Johannes Kepler (1571-1630), for example, discovered three scientific laws of the motions of the planets by deducing them with the help of deductive rules and deductive abstraction from astronomical observations made by Tycho Brahe. For example, according to Filippo Graziani et al. (2021, 36), Kepler's First Law states: " The orbits of the planets are ellipses and the Sun is at one focus." A scientific law describes a static state of affairs, such as the form of the planet's orbit. In addition to deducing universal scientific laws, science also uses deduction to discover the causes that make physical phenomena understandable (Cf. Pohar 2021).

(2) The mantle of reality is the lifeworld or the world of lived experience. With the help of the inductive method (e.g., Hume's generalization) which is based on inductive abstraction, scientists discover general laws (e.g., Newton's Laws of Motion), laws of nature (e.g., the law of evolution, which states that living beings are adaptable in their nature) and the essences (e.g., the essence of evolution is adaptedness) of natural phenomena. Science is thus not just about observation and deduction. Modern science was a breakthrough because of the implication of inductive reasoning, which some even considered the "essence of scientific method" (Stanford Encyclopedia of Philosophy 2021, s.v. "Scientific Method"). We need another type of perception of meaning, other than observation: lived experience, which is internal instead of external sense-experience. To discover invisible laws of nature and essences, one needs to do experiments, which are events that provoke a change in the state of affairs. We can experimentally confirm, for example, that a wooden board breaks under a certain load if we place different weights on it. When a board breaks, there is a change in the observable state of affairs from the state of unbrokenness to the state of the brokenness of the board, and one can experience its breakage, thus perceiving the meaning of the inner lifeworld or flesh of the world. From the multiple cases of experiencing the breakage of a wooden board, one can reason by induction to the general law, that a wooden board, on which a heavy weight is placed, probably breaks.

(3) The outer core of reality is material life, which can be experienced and comprehended with abductive reasoning, which produces explanations that make sense of surprising phenomena. Science is much more than deduction and induction. The triumph of modern science was reached on the basis of abductive reasoning, the origin of scientific theories. With the method of inference to the best explanation, we can find the most suitable theoretical explanation, as we will explain below. Modern science is pursuing the "theory of everything," which has become the Holy Grail of 
postmodern humanity. Abduction is the most mysterious of scientific reasonings as there are no rules about how to make a theory, and imagination is also at work, which most people do not correlate with scientific knowledge. Abduction does not process observations of states of affairs nor lived experiences of events, but the felt experiences of something happening (e.g., the molecular processes in an animal cell), which is the substrate from which explanatory theory is created. However, there can be no felt experience of something happening if there is no prior observed state of affairs and lived experience of an event. The first step in understanding is made by observing the world, so observation is the basic and most fundamental kind of perception.

(4) The inner core of reality of personal life, which can also be experienced, and the true human identities can be discovered on the basis of this experience. The purpose of science is also to explore the nature of human identities, including our professions, which are forms of personal life. Science needs to comprehend who an evolutionist is, who a doctor is, a scientist is, and even who a father or a mother is. If there are misconceptions about human identities, no progress of society is possible. Science is the driving force of human progress, the goal of which must be the discovery of true human identities. Psychology has revealed many pathologic features of certain identities, which need to be deleted from our lives. For example, for the Nazis, a scientist was a person who conducted experiments on humans. Fortunately, the world has condemned this form of scientific identity. Our personal lives have many pathogenic features. It is the purpose of science to find true forms of our identities, and this is in the domain of Humanities, Geisteswissenschaften in German, which can be translated as Sciences of Spirit. This fourth ontological layer is thus spiritual in its nature and is situated in the innermost and the most turbulent or dynamic part of reality.

\section{The phenomenological method}

As said above, the phenomenological method belongs to a class of inductive methods that analyze the essential eventful interiority of the world (i.e., its flesh). However, it is important to emphasize that the exteriority and interiority of the world are not separated but are thoroughly interconnected. Branko Klun $(2017,504)$ says:

The phenomenological approach calls into question the naive distinction between the immanence of subjective interior and the transcendence of the external world of objects. Consciousness is not "inside," and the world is not "outside." The cognitive subject is always already outside, and besides things, things, however, are always revealed within the experience and cognition exercised by the subject.

There are many different conceptions of phenomenology (cf. Krupp 2010, 1032). However, regardless of how the notion of phenomenology is defined, for Dan Zahavi $(2019,44)$, the task of phenomenology is

...not to describe empirical and factual particularities but to investigate the essential structures characterizing our experience, their correlates, and 
the connection between two. As philosophers, our concern is not primarily with accidental features and properties but with necessary and invariant ones.

Edmund Husserl developed a method for finding essential structures called "eidetic variation," which is described by Zahavi $(2019,45)$ as follows:

The basic idea is here to take our point of departure in what is given to us and then to use our imagination. By varying that, which we are investigating, by imagining it being different from how it actually is, we can slowly strip away its accidental properties and thereby reach certain properties or features that cannot be changed without the object of investigation, thereby also ceasing to be the kind of object it is.

Zahavi $(2019,45)$ also warns that we should be aware that this method is an "open-ended process, and the results are in most cases defeasible. There is, in short, no claim to infallibility". Given that the phenomenological method is an inductive method, we cannot even expect any certainty because induction is related to probability.

\section{The method of inference to the best explanation}

With this inductive method, it is possible to determine which of the abductively acquired theories is the best. When performing an inference to the best explanation, we evaluate several competing hypotheses to determine which one is the "loveliest," meaning which one fares best when we compare their various epistemic virtues (they will be listed in the following). We then infer that the loveliest explanation is the most likely to be true (Lipton 2004, 143). According to Alan Musgrave (2010, 93), inference to the best explanation can be represented by the following scheme:

It is reasonable to believe that the best available explanation of any fact is true.

$F$ is a fact.

Hypothesis $\mathrm{H}$ explains $\mathrm{F}$.

No available competing hypothesis explains $\mathrm{F}$, as well as $\mathrm{H}$, does.

Therefore, it is reasonable to believe that $\mathrm{H}$ is true.

McGrath $(2009,84)$ says that surprising facts can be defined as "things that surprise us because they are counter to normal expectations, and hence force us to ask whether there is another way of looking at them." Thus, surprising facts cannot be circumvented without finding an explanation that gives them meaning and turns them into expected facts. This is also true for the surprising fact of true love.

Postpositivism created a new definition of the explanation, whose main purpose is making sense of the world and life. Here, the task of explaining is clearly subordinate 
to the quest for understanding (Clayton 1989, 37). The best explanation is one that makes sense of observations and other kinds of experience (lived, life, and personal experience) so that no surprising facts remain within its perspective. The success of an explanation in making sense of the world and life can be estimated by weighing the epistemic values. There is, however, no uniform opinion among philosophers on the most appropriate set of values, and different authors propose different values. Because of the lack of space, we will mention just two, which are important for our analysis.

According to McGrath, empirical fit or empirical adequacy is the best way to choose the best one among competing theories. He $(2011,26)$ says: "The 'best' explanation may not be able to account for all our observations. But it ought to be able to account for them to a greater extent, and in a more plausible manner, than its alternatives." Because there is an objective empirical fit, one can experience a subjective resonance, especially in the case of Christianity. For McGrath $(2008,17)$, "the explanatory fecundity of Christianity is affirmed, in that it is seen to resonate with what is observed." We will take it one step further and argue that the best explanation is able to account not only for observations but also for other kinds of experience, in our case, the lived experience of true love.

The second important value of the explanation is the absence of ad hoc auxiliary hypotheses, meaning hypotheses that are subsequently added to a theory in order to negate the negative empirical evidence. While the philosopher Karl Popper was opposed to such ad hoc modifications, the history of science shows this to be a frequent occurrence in practice (Folse 2005). However, such ad hoc additions are generally considered a sign of the degeneration of the hypothesis.

\section{ADVANTAGES OF THE TRINITARIAN NATURAL THEOLOGY}

\section{Trinitarian natural theology is the search for a resonance between different kinds of experience and the Christian doctrine or worldview}

The analysis thus far has demonstrated that inference to the best explanation is a legitimate method from the point of view of the postpositivistic plurality of methods. It is also important to recognize that this method is not limited to the scientific context but is used in everyday life, for its origin is the lifeworld. McGrath and some other authors go even further and use the method of inference to the best explanation to determine which worldview is the most rational and claim that it is actually the proper method of Trinitarian natural theology. It must be emphasized that God as the best explanation for observations is not a theory competing with scientific theories (that would be a case of God-of-the-gaps) but a theory competing with metaphysical naturalism and other worldviews, which are not scientific theories but paradigms.

Christianity and metaphysical naturalism are two worldviews that belong to a group of philosophical explanations that must give meaning to the totality of experience. All experience must be in resonance with the worldview; otherwise, the worldview is faulty. Richard Dawkins (1995, 133), too, admits the need for the agreement between a worldview and observation: "The universe we observe has precisely the properties we should expect if there is, at the bottom, no design, no purpose, no evil and no good, nothing but blind, pitiless indifference." However, 
Alister McGrath does not agree with Dawkins' statement, and neither do we. We will justify our disagreement with him on behalf of the Argument from True Love.

McGrath's choice of Christian worldview included weighing the abovementioned epistemic values, with empirical fit mentioned first. This empirical fit, which gives rise to the experience of the resonance, according to him $(2009,20)$, confirms the fact that "fundamental themes of the Christian faith offer the best explanation of what is seen." Trinitarian natural theology does not intend to deductively prove Christian beliefs, for its agenda is the abductive confirmation of the resonance between the theological explanations and experience. « (cf. McGrath 2008, 234). According to McGrath, the Christian worldview resonates with the observation and theories provided by science: the Big Bang theory, fine-tuning or the anthropic principle, the cosmic order, and other phenomena are fully consistent with the expectations of the Christian doctrine, including the phenomenon of true love. Our Argument from True Love can be formally written as follows:

Major premise: If the Christian worldview is true, then we will be able to perceive the resonance between Christian doctrine and our experience of the world and life.

Minor premise: We perceive the resonance between Christian doctrine and our experience of true love.

Conclusion: It is possible that the Christian worldview is true.

\section{Trinitarian natural theology is not just another example of "God-of-the-gaps"}

As advocated by McGrath, Trinitarian natural theology avoids the criticism of being just another case of "God-of-the-gaps."

First, unlike scientific theories, the purpose of which is explaining only individual observations and other experiences or parts of the world, Trinitarian natural theology aims to explain the totality of experience: This means that a good worldview must make sense of all experiences and their first- and second-grade explanations, not just some of them. There should not be any gaps here; it must explain the whole and not just individual parts. From the Christian paradigm perspective, all experiences and all their explanations must make sense. This applies, for example, both to the phenomenon of the Big Bang and to the phenomenon of true love, both of which make perfect sense from the Christian perspective and thus provide us with the experience of resonance. The Christian paradigm does not intrude on the place of scientific explanations but, as an umbrella paradigm, it makes sense of all different experiences and all their explanations, no matter how many there are.

Second, unlike some forms of classical natural theology, trinitarian natural theology does not abductively infer the existence of God from surprising facts as one of their possible explanations - in that case, God would be a competing theory to scientific theories. It works in the exact opposite way because faith comes before intellect. McGrath $(2009,57)$ says: "The approach I adopt argues for the greater 'empirical fit' of a Trinitarian worldview with what may be observed of the natural world, human reason and experience, and culture in general." The Christian worldview 
emerged much earlier than modern science, which means it was not created by Christians later as a response to experience. This means that there are no surprising facts not because we abductively inferred a good theoretical explanation but because the pre-existent Christian doctrine is in resonance with modern scientific observations.

Third, the Christian doctrine of creation gives us not only the theoretical explanation of the world but also causal ones. Moreover, it does not give a causal explanation of individual observations, especially those that science cannot explain (this was William Paley's mistake), for that would mean that a theological causal explanation would compete with scientific causal explanations. Instead, the creation doctrine gives us the theological causal explanation, which explains the contingency of the whole (i.e., the world or the entirety of creation), a contingency inferred on the basis of the contingency of individual parts. We cannot observe the contingency of the world itself but can only infer that the world itself is contingent. According to Christian creation doctrine, the theological cause of the contingency of the world is God's decision to create it as such. And we expect the theological causal explanation to be in resonance with scientific causal explanations of the contingency of the world. Our mountain-body model of understanding (Cf. Pohar 2021) assumes the existence of such a scientific causal explanation for contingency and predicts that it will not be a rival to the theological explanation but will be in resonance with it.

Fourth, Trinitarian natural theology does not rely on any theory about the world. The doctrine of creation says nothing specific on the entities that constitute the world as a whole; it can be a single universe, a multiverse, or something else. Metaphysical naturalists, in contrast, sometimes base their naturalism on a certain theoretical explanation that supposedly supports the materialistic worldview. New atheists are often partisans of the multiverse theory because this theory fits well with the materialist framework. However, from the Christian perspective, it does not matter which theory of the universe that we take for granted because there can be hundreds of different possible theories, as long as they are in resonance with Christian doctrine, as is the case with the Big Bang and Multiverse theory.

Fifth, in contrast to the pagan mythological universe in which celestial objects, including Earth, are divine, Trinitarian natural theology assumes a disenchanted and relatively autonomous nature of the world that is essentially good. This means that the material world functions in accordance with relatively autonomous principles, which were created by God. There is no need for God to be directly responsible for the emergence of complex molecular mechanisms; secondary causes can perform the set task on their own. Basing our view of the world on the Bible renders it impossible to be pessimistic, as it is with the God-of-the-gaps theology, where God must intervene again and again for nature to function properly. Trinitarian natural theology thus presupposes methodological naturalism.

\section{Trinitarian natural theology is not ad hoc}

Not only is Trinitarian natural theology in good resonance with observation and other kinds of experience, but there are also good reasons why it should not be treated as an ad hoc creation. The first reason the creation doctrine is not ad hoc is that there are practically no ad hoc hypotheses with the help of which it would have to adapt to 
our experience of the natural world. McGrath $(2009,58 ; 121)$ claims that a possible criticism could be that empirical fit is the consequence of an ad hoc theology, which was at its conception adapted to the empirical reality so that the empirical fit was strong. Therefore, possible critics could claim that this theology was invented as a response to what can be observed. Christian theology, however, did not invent explanations for observations such as the Big Bang theory, anthropic phenomena, finetuning and comprehensibility of the creation; they resonate with the pre-existing thought. While these surprising facts were only revealed with the advancement of modern science, Christian theology, which resonates with them, is more than 1000 years old. Resonance was discovered by advanced modern science. Surprising phenomena are explained by a theology that is much older than them.

The second reason why the creation doctrine is not ad hoc originates from the fact that our experiences of the world resonate with our expectations (which are aroused in us by a good explanation) from the very beginning. From the perspective of an individual worldview, an observation conducted within the world can be either reasonable and expected or unreasonable and contrary to expectation. Therefore, if a worldview is correct, all experience must be given meaning, without the excuse that a certain surprising fact will be given a meaning sometime in the distant future with new discoveries. Metaphysical naturalists, for example, wait for the discovery of the scientific theory, which will allegedly make the anthropic principle an expected phenomenon. But if metaphysical naturalism is the correct worldview, then the finetuning of the universe should in no case come as a surprise, even before the very discovery of scientific theory, as is in the case of Christian doctrine. We could even speculate that in the case of discovering the scientific explanation of the anthropic principle, this explanation would be an even greater surprise for metaphysical naturalists than the anthropic principle itself and would, for this reason, need even higher explanations. Moreover, in contrast, we can be certain that this newly discovered scientific material cause of the anthropic principle would be even in greater resonance with the Christian doctrine of creation than the anthropic principle itself.

\section{THE ARGUMENT FROM TRUE LOVE}

\section{The Principle of Insufficient Reason is an extra-worldly manifestation of true love}

There is a historical controversy regarding the difference between reasons and causes. For the rationalistic way of thinking in the Age of Enlightenment, a reason and a cause were considered one and the same thing (Lat. causa sive ratio), which is the reason "a sufficient explanation may be understood either in terms of reasons or causes" (New World Encyclopedia, s.v. "Sufficient reason, principle of”). In modern philosophy, some distinguish cause as an ontological and reason as an epistemological concept. For example, the reason for the statement "Some of the vertebrates are penguins" is the presupposed premise "All the penguins are vertebrates" (Uršič and Markič 2009, 7). In accordance with this last conception of the difference between a reason in a cause, we claim that a reason is a part of an explanation, the purpose of which is to make sense of the world and life. Thus, it can happen that a cause becomes 
one of the reasons in the explanation, which makes sense, as is true in the following case, in which God as the First Cause becomes one of the reasons in the explanation that makes sense of the surprising fact of true love.

Equipped with this knowledge, we can now proceed with our rational analysis of the phenomenon of true love. We will use the findings of the renowned phenomenologist Jean-Luc Marion and apply them to our Argument from True Love. We will start with the observations made by Marion, specifically that in the material world, true love appears to lack any reasons for actions, meaning that the deeds of true love apparently lack reciprocity. From these observations, he logically deduced The Principle of Insufficient Reason as an extra-worldly manifestation of true love.

According to Marion $(2007,78)$, true love is characterized by the transgressing of reciprocity: "The lover appears when one of the actors in the exchange no longer poses prior conditions, and loves without requiring to be loved, and thus, in the figure of the gift, abolishes economy." Reciprocity, which rules human behavior, is about calculating the costs of one's service. It can easily be observed that almost all our actions have clearly defined reasons, in accordance with the Principle of Sufficient Reason. However, Marion observes that this is not always the case. There are cases in which reasons for the actions seem to be absent. He $(2007,79)$ says: "In loving without reciprocity, the lover loves without reason, nor is he able to give reason - counter to the Principle of Sufficient Reason. He renounces reason and sufficiency." Marion warns us that the inability of giving reasons is not a person's deficiency but the consequence of the nature of true love. In his $(2007,79)$ words: "Love does not reject reason, but reason refuses to go where lover goes [...] When loving is at issue, reason is not sufficient: reason appears from this point forward as a principle of insufficient reason."

The Principle of Insufficient Reason could be formulated as follows: No act of true love should have sufficient reason to explain why it was performed. The phenomenon of true love not only apparently lacks any reasons but is even not allowed to possess them because the presence of external reason means the absence of love. A deed is recognized as true love only if it is made out of true love for a fellow human being. If a deed has some external reason (e.g., if I help someone to get praise), then it is not recognized as a deed of true love.

So, the external observer in the material world can easily observe that a loving person cannot give a sufficient answer to the question: Why do you love? To underline the veracity of The Principle of Insufficient Reason, Marion (2007, 79-80) gives the following three arguments:

First, if I love first, without any assurance of return, reciprocity can no more give me reason to love than it can tell me that I am wrong or give me a reason not to love: I remain as free to love as I am free not to love. Second, because I love first, I can sometimes very well not yet know the one that I love; not only because, in a radical sense, I have no need of knowing her and, on the contrary, the anteriority of my initiative dispenses me from having to, but also because the project of knowing this other adequately, without and even before loving her (as an object), has no meaning. Third, if I love without reason or even at times without prior 
knowledge of the figure or of the facets of the other, I do not love because I know what I see, but inversely I see, and I know in the measure that I, the first to love, love. The other appears to me for as much as I love her, for my anterior initiative does not solely decide my attitude toward her, but about all her phenomenality - because I am the first to put it on stage by loving her.

However, an extra-worldly manifestation of true love, which can be grasped as The Principle of Insufficient Reason, also has its interior lifeworld correlate, which cannot be observed with sense-perception but nevertheless can be experienced and rationally analyzed with the phenomenological method of eidetic reduction. Again, we will make use of Marion's findings, which reveal that true love, in essence, actually does not lack proper reason, for true love contains reason in itself. Thus, from the outside, it looks like true love lacks reason, but from the inside, reason is contained in love itself.

\section{Ratio-sui is an intra-worldly essential property of true love}

Love is the essence of being human. Unlike Descartes, the French phenomenologist Jean-Luc Marion $(2007,7)$ does not define man as a rational being but as a loving being:

Man loves - which is what distinguishes him from all other finite beings, if not the angels. Man is defined neither by the logos, nor by the being within him, but by this fact that he loves (or hates), whether he wants to or not. In this world, only man loves, for animals and computers, in their own way, think just as well as he, indeed better than he; but one cannot affirm that they love. But man does - the loving animal.

Love is also the essence of the Christian faith. Robert Petkovšek says: "Evangelical freedom is not finally realized through the formation of a moral person, but in service, in the fact that man fills the form of his humanity with love and selfgiving." (Petkovšek 2018, 49)

However, what is the essence of true love? This answer can be arrived at by analyzing the lifeworld experience of free donation of time, attention, material help, or any other form of true love performed by a loving person. The eidetic reduction has revealed that the essential property of true love, separating it from other phenomena, is its self-explicability, where explanandum (i.e., a phenomenon that is to be explained) is the same as explanans (i.e., the reason that explains explanandum). Our everyday experience tells us that explanandum and explanans are usually not the same. For example, the reason for the summer heat (explanandum) is the Sun (explanans), and obviously, we can not equate the heat and the Sun, because these are two different phenomena. But in the case of true love, this experience fails. The reason for true love is not some external reason but true love itself. The Apostle Paul says on the ideal of true love: "Do everything in love" (1 Cor 16:14). Therefore, when it comes to true 
love, love itself must be the reason for love, which means that true love is ratio-sui (i.e., the self-content reason). This is the crucial finding of the phenomenology of love, which was undertaken by Jean-Luc Marion. Crucial for our case are the following words of Marion (2007, 82): "From the lover's point of view (and his alone), love becomes its own sufficient reason"; in other words: according to Marion, true love is ratio sui. Love contains its reason within itself. It can be clearly seen that The Principle of Insufficient Reason is in resonance with the essence of true love and that the former is embedded in the latter.

When we rationally analyze a natural phenomenon, grasping its essence by phenomenological eidetic reduction enables us to make an essential definition of the phenomenon, which opens the possibility of discovering its theoretical explanation. However, this is just one part of the story. One also has to grasp the material principles of this natural phenomenon because only with their help is the theory created (i.e., the scientific theoretical explanation of the natural phenomenon). However, in the case of Christian doctrine, the theory, which makes sense of the surprising facts of The Principle of Insufficient Reason and self-explicability of true love, is not created but only recovered from the pre-existing Christian tradition, which has its origin in revelation, which means the explanation is not ad hoc. Of course, we could provide some ad hoc explanations which are always at hand, though, for example, "it is only an illusion" or "we will find an explanation of this strange phenomenon sometime in the future" but, as we said before, in science such ad hoc solutions are the sign of theory's degeneration and should be avoided.

God has revealed himself as Triune God of Love, in whom three divine persons, Father, Son, and the Holy Spirit, live in perfect communion, in true love. Next, we will explain how this Trinitarian theology makes sense of observed and experienced properties of true love. Of course, we can find some material cause for the surprising facts of true love and a material explanation that would explain them; nevertheless, there is a need for some final theological explanation, which would remove the element of surprise completely, which any material explanation is unable to do. Moreover, this theological explanation is not expected to compete with the scientific explanation but to be in resonance with it.

\section{The demonstration of the resonance between grasped self-explicability of true love and the Christian doctrine of Triune God of Love}

Now is the right time to apply the method of inference to the best explanation. The phenomena of true love are fully expected from the perspective of the traditional Christian doctrine, which, first of all, has an answer to the question of how the essential property of true love is self-explicability. The answer is in the Christian conception of the nature of God and the human being, as the central claim of Christian doctrine is that God is love (1 John 4:16) and that humans are created in the image of God (Genesis 1:27).

Christianity has the answer to the question about the nature or essence of God. The Bible reports that ignorance about the nature of God was a principal feature of the pagan faith. The Apostle Paul used this fact as the starting point of his teaching in Athens: 
Paul then stood up in the meeting of the Areopagus and said: "People of Athens! I see that in every way you are very religious. For as I walked around and looked carefully at your objects of worship, I even found an altar with this inscription: to an unknown god. So you are ignorant of the very thing you worship - and this is what I am going to proclaim to you" (Acts 17:22-23).

The Gospel is good news mainly because it announces we need not fear God since we essentially know and understand his essential nature, which tells us that it is in the nature of Triune God to love in the form of true love. Moreover, because loving out of true love is in God's nature, we shall not be afraid neither of Him nor of the possibility that probably there is no God, because our lifeworld experience tells us otherwise. And who should we trust, if not our experience?

However, for the doctrine of the God of Love to be consistent, it must be supplemented with the doctrine of the Holy Trinity. According to the Christian creed, there is one God in three persons, which resonates with the logical conclusion that perfect, true love must contain the relationships within itself. Therefore, it is logical that the God of Love exists in the form of three persons. For if God was only one person, He would not be true love because He would need to create someone to love him, or He would just love Himself, which would result in narcissism, which we do not consider to be true love. If God were only two persons, their love would not be true because it would be infertile, not open to new life, to the Other, and would thus be closed and selfish. But selfish love cannot be considered to be true love. God is true love because in Him there are three divine persons, of whom the Holy Spirit is the fruit of the love between the Father and the Son. This means that the mutual love between the Father and the Son is not selfish but fertile and open for the Other. The Father and the Son love each other out of true love (which means true love is the cause of their love because it dictates them to love each other), and from both of them proceeds the Holy Spirit, the personal bond of love and the reason for the existence of the Holy Trinity (i.e., Triune God). This means that God, as the Triune God, has the cause and the reason for its existence in Himself. It is because of true love that the Father and the Son love each other, and the Holy Spirit is also the reason for their relationship.

These last revealed truths about God are complemented with the findings of the first philosophy (i.e., metaphysics). We know from philosophy that God is selfsufficient, "having within Himself the sufficient reason for His own existence" (The New Catholic Encyclopedia, s.v. "Aseity (Aseitas)"), which resonates with the theology of Holy Trinity we have just presented. Self-sufficiency in the form of selfexplicability of true love has its origin in the Triune God of Love and is manifested in the world through human beings. The grasped self-sufficiency or self-explicability of true love in the world should come as no surprise because humans are also capable of acting out of true love, the same as God, for according to Christian doctrine, we are created in the image of God, which is the reason that we are able to love without reciprocity and act according to The Principle of Insufficient Reason. Thus, we can see that the Christian doctrine makes perfect sense of the grasped self-explicability or ratio-sui of true love. The reasons for this are the following reasons: God is Love, God 
is Triune, God is self-sufficient, and human beings are created in the image of God. All the reasons combined in a meaningful way explain or make sense of the perceived self-explicability of true love.

\section{The demonstration of the resonance between The Principle of Insufficient Reason and the Christian doctrine of perichoresis}

The perichoretic way of the communal life of the Triune God explains how it is that we humans act according to The Principle of Insufficient Reason. According to Ciril Sorč $(2000,181)$, the ancient Greek theological term perichoresis denotes "the unstoppable flow of the exchange of goods, all the way to the greatest good, which is life. It is a life happening which impregnates all pores of life. Perichoresis keeps open paths, makes them transitory so that individual persons are completely 'open space' for another person." Perichoresis for Sorč $(2000,186)$ means "the complete circumincession or being-in-one-another of the three Persons of God, their complete self-givenness, their life in indestructible community, where each Person of God lives completely in the other two, for the other and together with the other two Persons of God." (Our translation)

Moreover, because man is created in the image and likeness of God, he is also subject to the way of life, that is (of course analogously) similar to the way of life of the Holy Trinity, which is marked by the co-existence, ex-istence, pro-existence and in-existence of the Persons of God (Cf. Sorč 2012, 82-85). If the saved man is the "creation of the Holy Spirit," then the fundamental vocation to dwell for others and with others is outlined in him.

The dynamic relationship between the three Persons of God or their way of life can be described in many ways. Above all, it is about co-existence, which means that the three Persons of God are not subordinate or superior to each other but equal in dignity, glory, holinessand importance. The same should apply to human society. This kind of co-existence is not passive, for everyone must actively show love to each other in countless forms, thus letting them know that they mean a lot to them or that their presence in their lives is very important to them.

Second, the Persons of God are "outside" themselves (ex-istence). Any introversion is foreign to the Triune God. God's Persons are completely open to each other; they know each other and are interested in each other. Because they live outside of themselves, they are always available to the other and willing to accept and entertain him. In this way, they are emptied of themselves or even exnihilated, thus preparing the space for the Other. This is a beautiful program for human society, which is, sadly, driven by selfishness.

Third, abiding in God means being for others (pro-existence). This means that the Persons forget about themselves and give themselves completely to their neighbor. Being for others means caring for them, actively searching for them until finding them and living with them, and making themselves available to them. A selfish man does not think of the plight of others; only a merciful man is the one who has no peace until he finds the poor and serves them. The merciful Samaritan makes himself and his possessions completely at the disposal of another. 
And fourth, abide means for God to be in each other (Lat. in-sistere). This presupposes, first of all, that they prepare space for others in their life; on the other side, they find space for themselves in others. It actually means that they are at home with others and that the others are at home with them. Jesus said: "Those who love me will obey my teaching. My Father will love them, and my Father and I will come to them and live with them" (John 14:23). The way of life of the Holy Trinity is thus a model for unity between men and unity between men and God.

Moreover, this dynamic happening inside the Holy Trinity, the Triune God of Love, which has just been explained by a theory, is reflected in the way of life of human beings because we are made in the image of God. This theory makes sense of the Principle of Insufficient Reason because it gives us the reasons, which explain how it is that people act according to the principle. Because humans are created in the image of Triune God, we are capable of living according to the ideal of God's true love, and this is the reason that the Principle of Insufficient Reason can be observed and grasped. So, the phenomenon of the Principle of Insufficient Reason is expected from the perspective of the Christian doctrine of the perichoretic way of life of the Holy Trinity, which confirms the reasonableness of the Christian faith.

\section{CONCLUSION}

The Argument From True Love does not prove beyond any doubt that God exists. We had only confirmed once more that the Christian faith is reasonable and that the Apostle Peter was not talking in vain when he said to the Christians: "Always be prepared to give an answer to everyone who asks you to give the reason for the hope that you have" (1 Peter 3,15).

In fact, we have only done half the work in this article. Namely, we have judged that Christian doctrine successfully makes sense of the surprising phenomenon of true love, thus confirming its credibility. However, the method of inference to the best explanation is intended to find the best explanation among the various possible explanations, which means that the phenomenon of true love must be viewed from other worldview perspectives, such as metaphysical naturalism, which is one of the dominant worldviews of the West. The latter is defined by The Cambridge Dictionary of Philosophy (1999, s.v. "metaphysics") as follows: "The view, sometimes considered scientific (but an assumption rather than an argued theory), that all that there is, is spatiotemporal (a part of 'nature') and is knowable only through the methods of the sciences." It is also the only worldview that the author of this article is familiar with (apart from the Christian worldview to which he is committed) but does not have first-person experience of it; therefore, he does not feel competent to judge the reasonableness of metaphysical naturalism.

Postmodern philosopher Alasdair MacIntyre (1989, 364; 374) claims that an individual can adopt two competing traditions as the original one. Such individuals who speak the language of both traditions can hear the arguments of both traditions. To understand another tradition or to understand its standards of truth and justification, its reasonableness and reasoning, or speak its language as a second first language, one needs to gain a cultural, moral, and intellectual worldview of a foreign tradition. One 
must adopt this tradition and become a true member of this tradition. People who are capable of this can see things from the opposite perspective. MacIntyre $(1989,167-$ 168) also says that it is a rare gift of empathy and of intellectual insight. For example, Thomas Aquinas spoke the languages of two competing traditions as the first language, namely Augustinian theology and Aristotelianism. And we can say that there is no shortage of such extraordinary people even today. As a convert from atheism, Alister McGrath understands both the language of Christianity and the language of metaphysical naturalism and is able to assess which tradition better explains the phenomena of the world, including the phenomenon of true love.

To conclude, let us repeat that our intention was not to give a God-of-the-gap argument for the existence of God in terms of a theological explanation that would replace a naturalistic one for the surprising phenomenological phenomenon of true love. Our mountain-body model even assumes that such a naturalistic cause and its explanation necessarily exist, although we are not familiar with it. From the point of view of Christian doctrine, methodological naturalism, which should not be equated with the metaphysical naturalism worldview, is a perfectly acceptable attitude. We argue, however, that a naturalistic explanation of the true love phenomenon will never be able to give a final explanation of this phenomenon, which will remain surprising until we add a theological explanation to this naturalistic explanation. Namely, the Thomistic doctrine claims that the chain of material causes cannot be infinitely long but that it must end somewhere with the First Cause.

In this article, therefore, we leave open the question, which are the material causes for the phenomenon of true love, how long the chain of material causes is, and whether the Christian worldview is the only or the best explanation of the phenomenon. As Pope John Paul II (1998, §33) says in the encyclical Faith and Reason, we are all friends and allies seeking the truth. Each of us has to do our best not to fail in this mission.

\section{REFERENCES}

Bem, Sacha and Huib Looren de Jong. 2006. Theoretical issues in Psychology: An introduction. 2. ed. London / Thousand Oaks / New Delhi: SAGE Publications.

Clayton, Philip. 1989. Explanation from Physics to Theology: An essay in rationality and religion. New Haven and London: Yale University Press.

Dawkins, Richard. 1995. River out of Eden: A Darwinian view of life. London: Weidenfeld \& Nicolson.

Dillon, Martin C. 1988. Merleau-Ponty's ontology. 2nd ed. Studies in Phenomenology and Existential Philosophy, James E. Edie, gen. ed. Bloomington: Indiana University Press.

Folse, Henry. 2005. Comments on Popperian falsificationism. Philosophy, College of Ars and Sciences, Loyola University, New Orleans. Available at http://www.loyno.edu/ folse/Popper.html. Accessed: February 7, 2017.

Garrison, James W. 1986. Some principles of postpositivistic philosophy of science. Educational Researcher 15 (9), pp. 12-18. https://doi.org/10.2307/1174713. 
Graziani, Filippo, Sergey Trofimovb, and Simone Battistini. 2021. Applied astrodynamics. In CubeSat Handbook. Edited by Chantal Cappelletti, Simone Battistini, and Benjamin K. Malphrus. London: Academic Press, pp. 35-52.

John Paul II. Faith and reason. Encyclical Letter. Vatican website. September 14, 1998. https://www.vatican.va/content/john-paul-ii/en/encyclicals/documents/hf_jpii_enc_14091998_fides-et-ratio.html

Klun, Branko. 2017. Transcendenca, samo-transcendenca in časovnost: fenomenološki razmisleki [Transcendence, Self-Transcendence, and Temporality: Some Phenomenological Reflexions]. Bogoslovni vestnik 77 (3), pp. 503-516. http://www.teof.uni-lj.si/uploads/File/BV/BV2017/03/Klun.pdf

Krupp, Tyler. 2010. Phenomenology. In Encyclopedia of Political Theory. Edited by Mark Bevir. Los Angeles: SAGE Publications, Inc., pp. 1032-1036.

Lipton, Peter. 2004. Inference to the best explanation. 2nd ed. New York, NY: Routledge.

MacIntyre, Alasdair. 1989. Whose justice? Whose rationality? Notre Dame, Indiana: University of Notre Dame Press.

Marion, Jean-Luc. 2007. The Erotic Phenomenon. Translated by Stephen E. Lewis. Chicago: The University of Chicago Press.

McGrath, Alister. 2006. The order of things: Explorations in scientific theology. Malden, Oxford in Carlton: Blackwell Publishing.

McGrath, Alister. 2008. The open secret: A new vision for natural theology. Oxford, UK: Blackwell Publishing.

McGrath, Alister. 2009. A Fine-Tuned universe: The quest for God in science and theology. The 2009 Gifford Lectures. Louisville, Kentucky: Westminster John Knox Press.

McGrath, Alister. 2011. Surprised by meaning: Science, faith, and how we make sense of things. Louisville, Kentucky: Westminster John Knox Press.

McGrath, Alister. 2012. Mere Apologetics: How to help seekers and sceptics find faith. Grand Rapids, Michigan: Baker Books, a division of Baker Publishing Group.

Musgrave, Alan. 2010. Critical rationalism, explanation, and severe tests. In Error and inference: Recent Exchanges on Experimental Reasoning, Reliability, and the Objectivity and Rationality of Science. Edited by Deborah Mayo and Aris Spanos. Cambridge: Cambridge University Press, pp. 88-112.

New Catholic Encyclopedia, s.v. "Aseity". Available at: https://www.encyclopedia.com/religion/encyclopedias-almanacs-transcriptsand-maps/aseity-aseitas. Last accessed: January 2, 2022.

New World Encyclopedia contributors. s.v. "Sufficient reason, principle of," Available at: https://www.newworldencyclopedia.org/p/index.php?title=Sufficient_reas on,_principle_of\&oldid=1030304. Last accessed: January 2, 2022.

Petkovšek, Robert. 2018. Svoboda med žrtvovanjem in darovanjem [The Freedom Between Sacrifice and Self-giving ]. Bogoslovni vestnik 78 (1), pp. 33-51. https://www.teof.uni-lj.si/uploads/File/BV/BV2018/01/Petkovsek.pdf.

Pohar, Borut. 2021. The Analogical Model of Cognitive Principles and Its Significance for the Dialogue between Science and Theology. Religions 12 (4), 230. https://doi.org/10.3390/rel12040230. 
Sankey, Howard. 2008. Scientific method. In The Routledge Companion to Philosophy of Science. Edited by Stathis Psillos and Martin Curd. Routledge Philosophy Companions. London and New York: Routledge, Taylor \& Francis Group, pp. 248-258.

Sorč, Ciril. 2000. Živi Bog: Nauk o Sveti Trojici. Priročniki Teološke fakultete 17. Ljubljana: Družina.

Sorč, Ciril. 2012. Povabljeni v Božje globine: Prispevek $k$ trinitarični duhovnosti. Znanstvena knjižnica 27. Ljubljana: Teološka fakulteta Univerze v Ljubljani z Inštitutom za sistematično teologijo.

The Cambridge Dictionary of Philosophy. 1999. s.v. "metaphysics". Edited by Robert Audi. 2nd edition. Cambridge: Cambridge University Press.The Stanford Encyclopedia of Philosophy, s.v. "Scientific Method," by Brian Hepburn and Hanne Andersen. Available

at https://plato.stanford.edu/archives/sum2021/entries/scientific-method. Accessed: October 5, 2021.Uršič, Marko and Olga Markič. 2009. Osnove logike. Ljubljana: Znanstvena založba Filozofske fakultete.

Zahavi, Dan. 2019. Phenomenology: The basics. Translation. London: Routledge, Taylor \& Francis Group. 